\title{
US Assessments of Japanese Ground Warfare Tactics and the Army's Campaigns in the Pacific theaters, 1943-45: lessons learned and methods applied
}

Pragmatism, coupled with a rational comprehension of the enemy's combat potential, characterized the US Army's evaluations of its Japanese counterpart during the Pacific War. In February 1943, the Joint Intelligence Center, Pacific Ocean Areas (JICPOA) explained, 'with more than a year of war behind us and with experience gained in fighting... we can begin to see how much we have misunderstood the [Japanese]'. ${ }^{1}$ Prior to the outbreak of the conflict, the Imperial Japanese Army (IJA) was underestimated as a second-rate force which did not possess the tactical skill to challenge its western counterparts. The Allied defeats in Southeast Asia during early 1942 resulted in a dramatic reversal of perceptions. After the fall of the Philippines, the Japanese were seen as an opponent whose fighting capabilities were at least on equal terms, or in some cases, superior to those of the US Army. Especially when it came to conducting operations in undeveloped terrain and the deployment of infantry units, the IJA clearly demonstrated an ability to outmaneuver its opponents. When the Americans achieved their first victories against the Japanese during the campaigns at Guadalcanal and in New Guinea in January 1943, the army establishment began to see its opponent in a more realistic light. Observations of the IJA's performance on the battlefield forces led US military intelligence to conclude that the enemy was hindered by a number of weaknesses, the most notable of which were a shortage of modern weapons and a lack of skill in their use.

At the same time, US intelligence was reluctant to discredit Japanese combat potential, for a number of reasons. In spite of its shortage of equipment, the IJA's infantry arm continued to prove adept at inflicting delay and attrition on Allied forces. In offensive operations, measures involving stealth and surprise were used to outflank the US army's positions. In defensive operations, the Japanese proved capable of imposing considerable

\footnotetext{
${ }^{1}$ United States National Archives and Records Administration, College Park, MD, (NARA 2), RG 165, War Department, Security Classified Publications, (hereafter, 'P' File), Box 472, JICPOA, Bulletin 12-43, Japanese Land Forces, No.6, 18 February 1943. All documents, unless otherwise specified, were consulted at NARA 2.
} 
obstacles. Commenting on the Buna operation, the Military Intelligence Service (MIS) of the US War Department noted, 'it would be impossible to overstress the tenacity with which the Japanese clung to their defensive positions'. ${ }^{2}$ Bunkers were constructed to provide protection against heavy bombardment, and enemy troops also showed their propensity to fight until they were killed. The possibility of improvements also could not be ruled out. As the campaigns in the Asia-Pacific theaters progressed, the IJA demonstrated a capacity to introduce nominal advances in its methods and weaponry. The results were often sufficient to raise concern. Military intelligence staffs used the information which American forces gained through their encounters with the Japanese to formulate an objective evaluation of the enemy, and enable combat personnel to gain a clearer picture of the challenges they faced.

For army commanders who served in the Pacific theaters, the information which they secured through combat experience provided an insight into the types of obstacles that the Japanese could be expected to up, as well as indications regarding the countermeasures which US forces needed to undertake. The basic doctrine of a combined arms battle, where infantry units operated in close conjunction with supporting arms to neutralize the enemy, proved adequate. Nevertheless, the application of the doctrine depended on the individual commanders' judgment of the resistance which the Japanese put up during a particular operation. Furthermore, even when the US Army overcame its opponent, the achievement did not negate the fact that a substantial effort was needed. Oftentimes, the only reassurance was that the Americans had developed the capability necessary to dislodge the IJA from its garrisons.

\section{Historiography: the significance of US perceptions of the Japanese army during the Pacific War}

The campaigns against the Imperial Japanese forces in the Asia-Pacific theaters were primarily fought at sea and in the air. It was the US Navy and Army Air Force which carried out the economic blockade of Japan's oceanic supply lines and strategic bombing

\footnotetext{
${ }^{2}$ RG 165, War Department, 'P’ File, Box 1203, MIS, Intelligence Bulletin, Volume 1, No.9, May
} 1943 
campaign against its home islands, both of which played a vital role in crippling the enemy's war effort. However, the Army was needed to evict the IJA from its strongholds, and to occupy the islands which naval and air forces used as their advanced bases. Between 1943 and mid-1944, US Army operations were mainly undertaken in the Southwest Pacific Area (SWPA), under the leadership of General Douglas MacArthur. (See Map) The Sixth Army, commanded by General Walter Krueger, conducted a series of pincer movements on New Guinea and the surrounding islands. The initial aim was to isolate the Japanese navy's stronghold at Rabaul. When this was achieved, the objective was to secure a base within striking distance of the Philippines, which MacArthur wished to use as a staging area for an intensified campaign against the heart of Japan's empire. In the central Pacific, the recapture of Japanese-held islands was mostly undertaken by the Marine Corps. Nevertheless, the army deployed a number of units for the operations in the Gilbert-Marshalls area and in the Marianas archipelago. The Tenth Army was also deployed to capture the Japanese island bastion of Okinawa in April 1945.

Contemporary accounts and the secondary literature on the Pacific campaigns have invariably attributed the IJA's tactical skill as one of the foremost obstacles. Indeed, Japanese combat methods showed a curious mix of backwardness and ingenuity. ${ }^{3}$ On one hand, their demise was mainly due to the failure to match Western standards in the development of modern weapons and training in their use. Army doctrine placed infantry units as the centerpiece of battlefield operations, and while the practice was logical, given Japan's narrow industrial base and subsequent difficulties in producing mass quantities of heavy equipment, the weakness also stemmed from perceptual faults. Field commanders maintained that foot soldiers, when properly led and motivated, could overcome all

\footnotetext{
${ }^{3}$ Following analysis is based on A.J. Barker, Japanese Army Handbook, 1939-1945 (London: Ian Allan, 1979); A.D. Coox, 'The Effectiveness of the Japanese Military Establishment in the Second World War', in A.R. Millett and W. Murray (eds), Military Effectiveness, Volume III: the Second World War, (Boston: Allen \& Unwin, 1988), pp.1-44, and idem., 'Flawed Perception and its Effect Upon Operational Thinking: the case of the Japanese Army, 1937-41', in M. Handel (ed.), Intelligence and Military Operations (London: Frank Cass, 1990), pp.239-54; E. Drea, In the Service of the Emperor: essays on the Imperial Japanese Army (Lincoln: Nebraska UP, 1998); G. Forty, Japanese Army Handbook, 1939-1945 (Stroud: Sutton, 1999); and S. Hayashi, in collaboration with A.D. Coox, Kogun: the Japanese Army in the Pacific War (Quantico, VA: Marine Corps Association, 1959).
} 
elements.

The IJA's ability to innovate was hindered by a military culture which discouraged moves to address any deficiencies that affected its performance. ${ }^{4}$ Training was conducted in such a way as to instill an unquestioned acceptance of orders from higher authority, and officers lacked 'the ability to undertake an objective assessment of their own actions'. ${ }^{5}$ As a result, tactical methods were characterized by inflexibility. The Japanese also tended to underrate their opponents. Western forces, including the US and British, were considered to be lacking the stamina to withstand the rigors of prolonged combat, and thus unable to match the IJA in terms of staying power, in spite of their preponderance in weaponry. ${ }^{6}$ Even after the Allied counter-offensive gained pace in 1943, and US forces began to systematically oust the Japanese from their garrisons, army officials did not comprehend that their troops could not always defeat better equipped opponents. An appreciation of Allied tactics, based on the Moto unit's operation in New Guinea, maintained, 'the enemy is thoroughly materialistic and trusts only in the power of material things'. ${ }^{7}$ Against such an opponent, the Japanese soldier's morale was to be 'most fully manifested'. Even when faced with overwhelmingly superior fire power, a 'firmness of spirit on the part of officers and men' was supposed to 'insure' a successful defense. ${ }^{8}$ In the end, the Japanese army’s rigid approach to military operations resulted in a profligate expenditure of resources.

In spite of its faults, the IJA was capable of putting up a significant challenge. Japanese troops rarely failed to show their willingness to sacrifice their lives for their nation's cause, and fought literally to the last man and round. Infantry units managed to circumvent the weaknesses stemming from their lack of equipment by devising what

\footnotetext{
${ }^{4}$ Coox, ‘Japanese Military’, pp.34-38

${ }^{5}$ Drea, Service of the Emperor, p.72

${ }^{6}$ Coox, 'Flawed Perception', pp.252-3; Hayashi, Kogun, pp.23-27

${ }^{7}$ MacArthur Memorial Library and Archives, Norfolk, VA, (MML), RG 3, Box 124, ATIS, SWPA, Enemy Publication, No.37, Allied Combat Tactics, captured at Cape Dinga, July 1943, translated 22 August

${ }^{8}$ RG 127, Records of the US Marine Corps, World War II Subject File, Box 54, CINCPACCINCPOA Translation, Combat Regulations for Japanese garrison units, 18 August 1944
} 
often proved to be imaginative ways of outmaneuvering and forestalling their opponents. In the short term, Japanese troops proved adept at making optimum use of what they had in order to delay the US Army's operations in the Pacific.

American perceptions concerning the IJA's combat performance therefore constitute a significant subject for historical research, and yet, it remains largely unexplored. A number of publications, including official histories and academic monographs, have provided useful insights into the challenges which the US Army faced. ${ }^{9}$ First-hand accounts have put forward some introspective reflections on how combat experience shaped American perceptions of the Japanese. ${ }^{10}$ However, the existing works have mainly provided a detailed narrative of the campaigns in the Asia-Pacific theaters, without documenting the evolution of opinions concerning the IJA's tactical methods and the most effective means for coping with enemy forces. The scholarship on US military intelligence has focused on the efforts made to decode Japanese communications. ${ }^{11}$

\section{Construction of the US Army's assessment of the IJA}

By 1943, the US Army's intelligence network in the Pacific theaters had evolved into an

\footnotetext{
${ }^{9}$ Official histories include: J. Miller, Jr., Cartwheel: the Reduction of Rabaul; P.A. Crowl and E.G. Love, Seizure of the Gilberts and Marshalls; P.A. Crowl, Campaign in the Marianas; R.R. Smith, The Approach to the Philippines; M.H. Cannon, Leyte: the return to the Philippines, and Triumph in the Philippines; R.E. Appleman, Okinawa: the last battle, in series The US Army in World War II: The War in the Pacific (Washington, DC: Historical Division, Department of the Army, 194481)

For unofficial accounts, see E. Bergerud, Touched With Fire: the land war in the South Pacific (NY: Penguin, 1996); S. Falk, Decision at Leyte (NY: W.W. Norton, 1966); B. Frank, Okinawa: the great island battle (NY: Talismann, 1978), W. Leary (ed.), We Shall Return!: MacArthur's commanders and the defeat of Japan, 1942-1945 (Lexington: Kentucky UP, 1988); J.F. Shortal, Forged by Fire: Robert L. Eichelberger and the Pacific War (Columbia: South Carolina UP, 1987); S.R. Taafe, MacArthur's Jungle War: the 1944 New Guinea Campaign (Lawrence: Kansas UP, 1998)

${ }^{10}$ R.L. Eichelberger, Jungle Road to Tokyo (London: Odhams, 1957); W. Gill, Always a Commander: the reminiscences of Major-General William H. Gill (Colorado Springs: Colorado College, 1974); W. Krueger, From Down Under to Nippon (Washington, DC: Combat Forces Press, 1953); J. Luvaas (ed), Dear Miss Em: General Eichelberger's War in the Pacific, 19421945 (Westport, CT, 1972); H. Riegelman, The Caves of Biak (NY: Dial Press, 1955)

${ }^{11}$ E. Drea, MacArthur's ULTRA: codebreaking and the war against Japan, 1942-1945 (Lawrence: Kansas UP, 1992); R. Lewin, The Other ULTRA: codes, cyphers and the defeat of Japan (London: Hutchinson, 1982)
} 
elaborate and coherent structure, with a clear division of responsibility. Each zone of command, including the Central Pacific, South Pacific, and SWPA, had its own central organization. The Joint Intelligence Center, Pacific Ocean Areas (JICPOA), with its headquarters at Honolulu, had control over the Central Pacific. In the South Pacific, the Combat Intelligence Center had jurisdiction over information gathered from POW interrogations and captured documents, while the Headquarters of the US army forces (USAFISPA), based at New Caledonia, processed reports on the IJA's performance. Similar arrangements were set up in the SWPA. The Allied Translation and Interrogation Service (ATIS) was a joint US-Australian operation, ${ }^{12}$ as was Headquarters Allied Land Forces. The sharing of intelligence between the various commands also became common. Intelligence summaries produced by SWPA headquarters contained many reports on operations in other theaters, and vice versa.

In regard to Japanese tactical methods, the source of information most frequently used was the multitude of combat action reports provided by US military personnel. Each Army group, including the Sixth and Tenth, along with the XIV and XXIV Corps, had its own intelligence section, designated G-2. In order to enable army commanders develop a more informed tactical doctrine for fighting the IJA, the intelligence services performed a number of tasks. First, the intelligence sections of the various army units forwarded their findings on Japanese combat methods and weapons to their respective commanders, as well as to the operations section, designated G-3. Action reports prepared by army units right down to the regiment level were most often followed by a lengthy series of appendices, including the G-2 intelligence reports. Although the reports focused on statistical information, such as enemy strengths, dispositions and orders of battle, they often provided accounts of enemy tactics, as put forward by officers who had engaged the Japanese. Furthermore, the G-2 sections of the Sixth and Tenth armies produced their

\footnotetext{
${ }^{12}$ For details, see RG 319, Records of the Army Staff, 'P' Files, Library Branch, Box 1822, General Headquarters, Far East Command, Operations of the Allied Translator and Interpreter Section, GHQ, SWPA, 12 July 1948. However, many of the opinions put forward regarding the effectiveness of US army intelligence operations in the SWPA are influenced by the personal biases of General MacArthur's chief of intelligence, Major-General Charles Willoughby. Same caveat applies to the document cited in Note 22.
} 
own weekly intelligence bulletins which contained a substantial amount of material on the IJA's combat skills. The sharing of opinions between G-2 and army field officers was evidenced by the extent to which their reports expressed similar conclusions regarding the challenges which enemy forces had put up.

Secondly, intelligence organizations regularly disseminated the reports prepared by the various combatant units. The MIS acted as the clearing house for IJA-related material. The G-2 regional file contained a wealth of information related to lessons learned through battle experience, and it constituted the main reference source which military intelligence drew upon for producing information bulletins and technical manuals. MIS publications, which included monthly summaries, as well as Tactical and Technical Trends, and Military Reports of the United Nations, not only provided descriptions of Japanese tactical methods. As the conflict progressed, the MIS began to propagate suggestions put forward by field commanders, concerning the procedures which were most effective for defeating enemy forces. Military intelligence staffs also became more expeditious at processing the information and disseminating their findings. In addition to publications, information was also distributed via intelligence studies that were regularly produced by the Far Eastern branch, and shared with army commanders upon request. ${ }^{13}$ Intelligence organizations at the theater level, including JICPOA, along with those working under USAFISPA and US Army Forces Pacific Ocean Areas (USAFPOA), also disseminated their own publications.

The extent to which intelligence reports on the IJA influenced the development of tactical doctrine was further evidenced by the fact that army officials often based their recommendations on information provided by the MIS and other informational organizations. For example, in 1945, the US Army Forces, Far Eastern theater, established the Pacific Warfare Board to determine whether it could prescribe certain solutions for dealing with the particular problems which US troops faced when fighting the Japanese. The contents were entirely based on information provided by the MIS's

\footnotetext{
${ }^{13}$ Naval War College, Newport, RI, Microfilm Collection, MF 218, US War Department, History of the Military Intelligence Division, 7 December 1941 to 2 September 1945, p.206
} 
dissemination section.

In addition to a more efficient intelligence apparatus, an important feature which aided the production of assessments on the IJA was a widespread culture of realism that pervaded the US army establishment. Military officials were aware that in order to defeat the Japanese, they needed to understand their ways of fighting, and thereby keep racial prejudices under control. On one hand, developing an accurate image was often fraught with problems, because opinions were shaped by a combination of fear and hostility. The Japanese army's rapid conquest of Southeast Asia during the opening stages of the war, followed by the difficult resistance which its troops put up against the Allied advance, created a popular belief among American soldiers that their enemy could be equated with ‘supermen' who had an uncanny discipline and fighting ability. ${ }^{14}$ The adversities which American front-line soldiers faced on the battlefield, and their opponent's practice of fighting to the last man, also gave rise to a widespread belief that the Japanese were a ruthless enemy who could be defeated only by extermination. The cultural divide which separated Allied troops from their adversaries fuelled further contempt. An army poll taken in 1943 indicated that about half of all GIs believed it would be necessary to annihilate the Japanese before peace could be achieved. ${ }^{15}$ American troops often felt they had to kill their Japanese opponent like 'one might exterminate a particularly intransigent pest'. ${ }^{16}$ In one of his first reports from the Pacific, war correspondent Ernie Pyle explained how the Japanese were 'looked down upon as something subhuman or repulsive; the same way some people feel about cockroaches or mice' ${ }^{17}$

Despite the prevailing animosity, American views were shaped by a considerable degree of rationality, particularly among officials who were responsible for matters such as intelligence analysis and military planning. The Japanese were portrayed as human beings with their own strengths and weaknesses. At MIS training courses, officers were

\footnotetext{
${ }^{14}$ J. Dower, War Without Mercy: race and power in the Pacific War (NY: Pantheon, 1986), p.9

${ }^{15}$ Ibid., p.53

${ }^{16}$ J. Ellis, The Sharp End of War: the fighting man in World War II (London: David \& Charles, 1980), p.320

${ }^{17}$ Ibid., p.78
} 
taught that some of the good qualities of the Japanese soldier were the fact that he was well-disciplined and 'very industrious', while his main weakness was his lack of initiative, and tendency to try the same methods even when they proved unsuccessful. ${ }^{18}$ Field commanders were also aware that if they wanted their troops to operate effectively, proper steps were needed to propagate a better comprehension of the Japanese. The main aim was to teach troops that the Japanese were a resilient foe, but ones who could be defeated, given adequate equipment and proper methods of use. Following the New Georgia operation, the XIV Corps concluded, 'our troops should realize the ability of the Japanese, but our training must give our men confidence that they are superior' in combat. ${ }^{19}$ The development of the US Army's assessments regarding the IJA was therefore driven by an awareness of the military necessities which American forces had to contend with.

During the early stages of the conflict, the main problem was that military intelligence organizations did not have a great deal of material to work with, aside from a limited range of combat experience in the Philippines, Guadalcanal and New Guinea. Willoughby's postwar memoir recalled the 'world-wide lack of accurate initial information on Japanese strength, resources, dispositions and orders of battle'. ${ }^{20}$ Until Allied operations in the Pacific gained momentum, army intelligence was not in a position to formulate a comprehensive assessment. Raw intelligence arrived in several forms. Captured documents and POW interrogations became increasingly available as the campaigns progressed. However, because the US Army was operating against 'an enemy with one of the world's most abstruse language systems', translation proved complicated. One of the most pressing problems that had to be overcome was the shortage of personnel

\footnotetext{
${ }^{18}$ RG 165, War Department, 'P’ File, Box 1305, Military Intelligence Training Center, (Camp Ritchie, MD), Japanese Combat Methods, 30 May 1944, (hereafter, Military Intelligence Training Center, Japanese Combat Methods); also see RG 226, OSS, Research and Analysis Branch Divisions, Intelligence Reports, Box 1480, File 129160, MIS Language School, (Fort Snelling, MN), Understanding the Japanese Army, October 1944

${ }^{19}$ RG 494, US Army Forces in the Middle Pacific (MIDPAC), Box 68, Headquarters XIV Corps, Lessons Learned from Joint Operations, 21 January 1944

${ }^{20}$ RG 319, Records of the Army Staff, 'P' Files, Library Branch, Box 1813, General Headquarters, Supreme Commander for the Allied Powers, Operations of the Allied Intelligence Service in the Southwest Pacific Area, 30 September 1950
} 
who had the necessary linguistic capabilities. ${ }^{21}$ Only a handful of US universities offered Japanese language courses. Americans who had resided in Japan did not possess a sufficient aptitude, since most of them had worked for Western companies and relied on locals to interpret and translate for them. ATIS started its operations with a miniscule staff, consisting of twenty-five officers and ten enlisted men. ${ }^{22}$ In a drive to resolve the problem, the MIS set up a special language school at Camp Savage (and later at Fort Snelling), MN. A large proportion of the instructors were second-generation Japanese immigrants (Nisei), and by the end of the war, almost 6,000 Americans received language training.

While captured soldiers and documents supplied information on the IJA's tactics, in the absence of further encounters with enemy forces, the intelligence left open to speculation the most pressing question, namely, the manner in which Japanese methods might affect the US Army's operations. The information secured from POWs was not always reliable. On one hand, captured soldiers showed an unusual desire to cooperate with their Allied interrogators. The phenomenon stemmed from the way in which the Japanese were indoctrinated into believing that when they fell into enemy hands, they lost all ties with their country. Prisoners thus did everything possible to win favor with their vanquishers, and divulged military secrets without hesitation.

At the same time, the few soldiers who fell into captivity usually represented the lower ranks, and lacked a knowledge of the IJA's tactical doctrine. Substantive information could be obtained only when the prisoners possessed an exceptional intellect. At Leyte, an artillery observer from the $26^{\text {th }}$ Division was able to provide a good amount of material on the methods used by Japanese artillery units, including reconnaissance, observation and fire control. ${ }^{23}$ However, similar instances were few and far between.

${ }^{21}$ U. Straus, The Anguish of Surrender: Japanese POWs of World War II (Seattle: Washington UP, 2003), pp.89-92

${ }^{22}$ RG 319, Records of the Army Staff, 'P' Files, Library Branch, Box 1822, GHQ Far East Command, Military Intelligence Section, Operations of the Allied Translator and Interpreter Section, GHQ, SWPA, 12 July 1948

${ }^{23}$ RG 165, War Department, 'P' File, Box 1206, G-2 USAFPOA, Intelligence Bulletin, No.9, 'A Japanese Artilleryman talks', from XXIV Corps, ATIS, SWPA, Advanced Interrogation Report, 
Captured documents were more useful, because they regularly laid out the main principles of Japanese army doctrine and their application in practice. The IJA's rank and file depended heavily on the written word, and tended to record every aspect of its operations in detail. The situation was further helped by the army command's faith that the complexities of the Japanese language precluded translation. When coupled with the institutionalized notion that the IJA was invincible, a situation arose where the most basic precautionary measures were overlooked. Troops often went into battle carrying sensitive material.

Documentary intelligence revealed a number of features related to the IJA's techniques, including its doctrine of conducting operations with a view to inflicting maximum attrition with limited resources. At the same time, the evidence could only illustrate the elements US forces were likely to encounter, and did not indicate how the Japanese might perform in combat. In defensive operations, the IJA aimed to alleviate the effects of Allied firepower while at the same time obstructing the enemy's movements. The defense plan for Salamaua called for the $51^{\text {st }}$ division to prepare all-round defenses, including 'belts of concealed positions connected with each other to prevent enemy infiltration'. ${ }^{24}$ Bunkers were sited so that the defenders could deliver fire against Allied forces approaching from every direction. Positions were to be held to the last man, and hostile troops destroyed by small arms fire. Defending forces were also to make take advantage of high ground in order to restrict access as well as to gain a better range of observation, while at the same time using natural objects for concealment. ${ }^{25}$ The documentation showed that the enemy had an elaborate doctrine, and accurately laid out the key elements which Allied forces had to deal with. Yet, without adequate combat experience, the manner in which the IJA's doctrine could affect its ability to engage its opponents remained open to speculation, and US intelligence hesitated to draw conclusions.

No.53, 2 February 1945

${ }^{24}$ MML, RG 3, Box 74, ATIS, SWPA, Bulletin No.291, Item No.1-3140, 'Instructions regarding the defense of Salamaua', captured at Bobdubi Creek, received at ATIS, SWPA, 19 August 1943

${ }^{25}$ MML, RG 3, Box 125, ATIS, SWPA, Enemy Publication No.52, Mabuku unit, Notes on Field Fortifications, captured at Jensen's, September 1943, translated 31 October 
Aside from POWs and captured documents, US intelligence also made use of combat action reports prepared by other Allied forces operating in the Asia-Pacific theaters, namely, the British-Indian XIV Army in Southeast Asia, and the Australian ground forces in New Guinea. Intelligence cooperation between the American and British armies was not satisfactory during the early stages of the conflict. In a manner similar to the US Army following the fall of the Philippines, in the aftermath of the IJA's victories in Malaya and Burma, the British produced a large volume of reports which described how enemy forces fought with a considerable degree of proficiency. ${ }^{26}$ When the Eastern Army undertook its first attempt to dislodge Japanese forces from the border regions of Burma during winter 1942-43, its troops faced further setbacks which compelled a closer scrutiny of enemy tactics. The newly-created XIV Army, commanded by General William Slim, carried out an extensive investigation of the challenges posed by the IJA's defensive methods, and the means by which they could be overcome. ${ }^{27}$ While a number of the reports did reach the Americans from summer 1942 onwards, exchanges do not appear to have been carried out on a regular basis. In particular, the inadequate liaison was acutely felt by British forces. Officers on the India-Burma front were unable to obtain information regarding the lessons which their counterparts learned during the operations in New Guinea and the Solomons. ${ }^{28}$ In June 1943, the British Chiefs of Staff dispatched the 220 Military Mission, headed by Major-General J.S. Lethbridge. Its purpose was to remedy the handicaps posed by 'the lack of reciprocal knowledge' between the Pacific and India-Burma theaters, concerning the tactical problems which Allied forces had to deal with. ${ }^{29}$ The Lethbridge Mission conducted an extensive tour of the SWPA theater, and produced a lengthy report on the operations carried out by US forces. However, the British, on their side, did not establish a systematic channel for forwarding their tactical intelligence to their counterparts, mainly because the two powers

${ }^{26}$ D. Ford, Britain's Secret War against Japan, 1937-45 (Abingdon: Taylor \& Francis, 2006), p.???; T. Moreman, The Jungle, the Japanese and the British Commonwealth Armies at War, 1941-45 (Abingdon: Taylor \& Francis, 2005), pp.47-51, 56-57

${ }^{27}$ Moreman, Jungle, the Japanese, pp.102-5, Ford, Britain's Secret War, pp.????

${ }^{28}$ R. Lewin, Slim: the standardbearer (London: Leo Cooper, 1976), p.119

${ }^{29}$ Ford, Britain's Secret War, p.??? 
were fighting in areas that were separated by a substantial geographic distance, with little prospect of carrying out a joint campaign.

At the same time, the British-Indian army did share its information on an ad hoc basis. The material obtained from the Burma front showed how the British often faced similar elements as those encountered by the Americans, the most notable of which were the obstacles which the Japanese tended to put up when operating in jungle terrain. The intelligence also revealed how the IJA could vary its tactics in battlefield conditions which US forces had not yet encountered. Two distinctive features were apparent, the first of which was the fact that in many areas, the ground was not covered by thick vegetation as was the case in the Pacific. At Guadalcanal and New Guinea, the Japanese frequently established their defenses on low, jungle-covered ground, whereas in Burma, positions were usually located on terrain heights and near the crests of mountains. ${ }^{30}$

Secondly, operations in Burma were conducted on a land mass, and supported by an intricate line of communications. Japanese forces had the opportunity to withdraw, rather than hold their positions to the last man and round. In autumn 1944, when British forces advanced towards the central plains, the $15^{\text {th }}$ Army retreated from the Chindwin river area. The move was covered with a series of rear-guard actions, fought principally by small units. Oftentimes, the Japanese occupied reserve positions that were 'very well chosen, had good fields of fire, and were well-camouflaged' ${ }^{31}$ However, American intelligence was able to interpret the information in a variety of ways, and could not provide comprehensive answers as to how the IJA might fare against the US Army.

The US Army's intelligence cooperation with the Australians worked in a considerably more smooth manner, mainly because the two armies worked in close conjunction during the campaigns in New Guinea and the Solomons. The circumstances were far more conducive to the sharing of intelligence. In fact, even at the theater level, SWPA

\footnotetext{
${ }^{30}$ RG 165, War Department, 'P’ File, Box 1203, MIS, Intelligence Bulletin, Volume 1, No.10, Section III: 'Some Japanese tactics observed in Burma', June 1943

${ }^{31}$ RG 165, War Department, 'P' File, Box 1204, MIS, Intelligence Bulletin, Volume 3, No.9, 'Japanese withdrawal tactics in Central Burma', May 1945
} 
headquarters and USAFISPA regularly disseminated reports prepared by Australian units in their intelligence bulletins and information summaries.

\section{Perceptions of the IJA and the development of tactical doctrine}

In order to conduct a successful campaign against the Japanese, US military personnel needed to determine how the IJA fought. For the purpose of developing an effective method to fight the IJA, a large part of the intelligence work was undertaken by field commanders. Army officers were tasked to collect information on enemy combat methods, and thereafter analyze the lessons learned from battle experiences. Action reports were passed up the chain of command, so that the army and corps headquarters could establish a more coherent set of tactics. While the provision of adequate equipment and technology was a key requisite, a proper knowledge of the challenges facing the Americans was frequently of equal importance. Intelligence on Japanese army tactics played a pivotal role in enabling US forces to deploy their resources effectively and thereby defeat their opponent. It laid the foundation for American doctrine, by providing information on the strengths and weaknesses of enemy combat methods. The formulation of an appropriate set of countermeasures took place after US forces gained adequate combat experience, and learned through experimentation which methods were the most effective.

The development of the US Army's combat methods during the Pacific War, and the influence of intelligence on the IJA, also needs to be examined against the wider background in which American doctrine developed. Tactical methods tended to rely on technology and firepower. The 1941 Field Service Regulations stipulated, 'no one arm

wins battles', and the combined action of all arms was 'essential to success'. ${ }^{32}$ The army was also staffed by competent generals, who made considerable efforts to train troops for battlefield situations. At the Command and General Staff College in Ft. Leavenworth, KA, graduates were taught to 'think, to analyze and to decide realistic courses of action'. ${ }^{33}$

\footnotetext{
${ }^{32}$ Drea, Service of the Emperor, p.61

${ }^{33}$ Ibid., pp.72-73
} 
Yet, while the US Army had the intellectual capacity to develop an effective set of methods, the main problem was that the War Department made minimal efforts to integrate the combined arms doctrine into a coherent practice. Lieutenant-Colonel Bradford Chynoweth, who sat on the General Staff at one point, wrote on the essence of the problem: 'the General Staff has quite frequently failed to make the basic unifying decisions which would serve to coordinate the arms’.34 An army-wide training program did not exist until $19411^{35}$

At the commencement of the war against Japan, the majority of US personnel were not trained to carry out a battle involving frequent movement and the coordination of arms. The infantry arm did not have an adequate number of skilled troops. At levels below the regiment, the bulk of the fighting was often carried out by a small number of riflemen. Although the Basic Field Manual: Jungle Warfare (FM 31-20), issued in December 1941, provided practical information on the matter, it did not envisage situations where US forces needed to overcome enemy defenses. ${ }^{36}$ The problems stemming from the lack of proper training became evident during the US Army’s failed attempt to stem the Japanese conquest of the Philippines during early 1942. Officers who participated in the campaign voiced concerns that their troops needed to adopt more flexible methods that were suitable for operations in underdeveloped terrain, where good communications were not available. In the Visayan islands, one commander abided by the traditional doctrine that called for defenses to be concentrated around main roads and positions. ${ }^{37}$ Against a Japanese army which habitually carried out infiltration and outflanking movements to bypass enemy lines, it was necessary to distribute troops and supplies in independent and mobile detachments. American troops also needed to be inculcated with the measures

\footnotetext{
${ }^{34}$ D.E. Johnson, Fast Tanks and Heavy Bombers: innovation in the US Army, 1917-1945 (Ithaca, NY: Cornell UP, 1998), p.182

${ }^{35} \mathrm{~W}$. Odom, After the Trenches: the transformation of US Army doctrine, 1919-1939 (College Station: Texas A\&M UP, 1999), p.204

${ }^{36}$ J. Luvaas, 'Buna: a Leavenworth Nightmare', in C.E. Heller and W.A. Stofft (eds), America's First Battles, 1776-1965 (Lawrence, KA: Kansas UP, 1986), pp.188-89

${ }^{37}$ MHI, Papers of Bradford G Chynoweth, The Military Engineer, 'Lessons from the Fall of the Philippines', Volume XLVI, No.313, September-October 1954
} 
they had to take in order to match their opponent's efficiency. A War Department training manual, based on information supplied by British officers in Malaya, via American observers, warned that the failure to prepare troops for combat conditions in the jungle 'will result in their being surprised both mentally and physically'. ${ }^{38}$ Likewise, the Japanese proved that properly trained troops could wrest the tactical initiative.

The US Army's methods of conducting offensive operations proved equally unsatisfactory. Owing to their lack of experience in fighting the Japanese in closed country, most unit commanders did not recognize the need for specialized training until they confronted the IJA at New Guinea in late 1942. Consequently, during the early stages of the Pacific campaign, front-line soldiers were burdened with the task of collecting information on how their opponent fought, and devising the appropriate countermeasures. General William Gill, commanding the $32^{\text {nd }}$ division, recalled how his troops learned about jungle fighting in Buna 'the hard way', and had 'to write [their] own book' on the lessons learned. ${ }^{39}$ Soldiers were initially trained only for frontal attacks, which proved costly. ${ }^{40}$ Eichelberger solved the problem by devising a plan whereby small patrol units were to scout enemy territory, and to call in mortar fire upon discovering a bunker. ${ }^{41}$ While the arrival of tanks enabled the attackers to take the initiative, advances could be made only by 'killing and digging out the Japanese occupying each bunker', a task that entailed 'a slow, tedious and difficult process'. ${ }^{42}$ The operations 'conclusively' demonstrated that US forces needed to undertake a more 'detailed, extended, and thorough training of the individual soldier and the squad, section and platoon leaders'. Japanese tactics in the defense had shown that attacks from the flank and rear provided 'the best opportunity for success'. ${ }^{43}$

At the higher end of the military command, officials recognized the need to gain a proper

\footnotetext{
${ }^{38}$ MHI, War Department, Training Circular No.55: Notes on Jungle Warfare, 18 August 1942

${ }^{39}$ MHI, Papers of William H Gill, Transcript of Interview

${ }^{40}$ Shortal, Forged by Fire, p.45

${ }^{41}$ Milner, Victory in Papua, pp.245-46

${ }^{42}$ RG 165, War Department, 'P' File, Box 2313, MIS, Tactical and Technical Trends, No.17, 'Tactics on Guadalcanal and New Guinea', 28 January 1943

${ }^{43}$ Shortal, Forged by Fire, p.61
} 
understanding of the IJA, so that could figure out the reforms that were necessary to improve the efficiency of their own forces. Jens A Doe, who commanded the $1^{\text {st }}$ infantry battalion at Sanananda, asserted that all units needed to use intelligence on enemy tactics to 'the fullest extent', so that training could take place with a realistic simulation of battlefield conditions. ${ }^{44}$ The fighting abilities which the Japanese displayed in defending their positions at Buna led General Robert Eichelberger, then commanding the I Corps, to set up a training program aimed at enabling US troops carry out the appropriate moves for overcoming enemy positions ${ }^{45}$ In order to determine the tactics which needed to carry out, army commanders used 'the standard tools of military intelligence'. ${ }^{46}$ Battlefield encounters with the Japanese were analyzed to discover what had gone wrong or right. The main task was to apply the doctrine of a combined arms operation in a manner that was suitable for defeating the IJA. The final report on Buna concluded, 'no new principles of warfare were learned', but the 'nature of the terrain and dispositions of enemy positions necessitated some novel applications of well known principles'. ${ }^{47}$ The encounter proved that artillery was useful in reducing Japanese bunkers, and thereafter, all infantry units were to be provided with high-caliber guns. ${ }^{48}$ At the same time, infantry units had to develop effective techniques of advancing against the IJA's lines and mop up the remnants of its opposition.

The information which the Marine Corps had concurrently gathered through its operations was also a valuable source of guidelines concerning the challenges facing US forces, and some of the ways by which they could be overcome. In 1943, the Government Printing Office published a collection of accounts provided by marines who participated

\footnotetext{
${ }^{44}$ RG 127, Records of the US Marine Corps, World War II Subject File, Box 58, Notes on Jungle Warfare, No.1: prepared by General Jens A Doe, (US Army), 27 April 1943

${ }^{45}$ Shortal, Forged by Fire, p.69-71

${ }^{46}$ S.P. Rosen, Winning the Next War: innovation and the modern military (Ithaca, NY: Cornell UP, 1991), pp.31-32

${ }^{47}$ Eichelberger, Jungle Road, p.75; also see RG 165, War Department, G-2 Regional File, Box 2153, File 6910, Report of the Commanding General, Buna Forces, Annex 3, G-3 Report.

${ }^{48}$ MHI, Papers of James F Collins, Final transcript of oral history, Conversations between General James F Collins and Colonel Wade Hampton, in series US Army Military History Research Collection
} 
in the Guadalcanal campaign. ${ }^{49}$ The material originated from officers of all ranks, ranging from those who commanded units at the battalion and brigade levels, to generals in charge of divisions. The reports demonstrated how many of the elements which had been faced in New Guinea were also prevalent in other areas of the Pacific theaters, and therefore provided relevant ideas. For example, enemy troops demonstrated their skill in screening their presence. Marine patrols thus needed to conduct a constant reconnaissance of their targets. ${ }^{50}$ Intelligence publications on the IJA began to include a substantial amount of material on how to neutralize its capacity to resist, thanks to a steady flow of combat action reports emanating from the Pacific theater. The Japanese demonstrated weaknesses that were open to exploitation. Practices such as the tendency to fight to the death, and conducting operations without concern for losses, could play into the hands of American troops, so long as they were properly trained, and inducted with a confidence in their 'superior ability to outthink, outshoot and outfight' their opponent. $^{51}$

Nevertheless, problems continued to stem from the fact that the Americans faced an unfamiliar enemy. In August 1943, Major-General O.W. Griswold, commanding the XIV Corps, noted how the particular techniques to be adopted in the Pacific theaters were 'not in the books'. ${ }^{52}$ Achieving success against the IJA often hinged on fighting a combined arms battle, where ground forces relied less on firepower, and more on the effective deployment of infantry units and supporting arms. The proper application of Allied material superiority was crucial, and firepower alone was rarely sufficient to 'exterminate the enemy', no matter how great the volume. ${ }^{53}$ The concept was not a significant departure from standard doctrine. In most operations, the basic principles, as taught in the

\footnotetext{
${ }^{49}$ See MML, RG 30, Papers of Richard K Sutherland, Box 26, Folder 12, Government Printing Office, Fighting on Guadalcanal, 1943.

${ }^{50}$ Ibid., Commentary by Colonel Merritt A Edson, Commanding Officer, Fifth Marines

${ }^{51}$ RG 165, War Department, G-2 Regional File, Box 2129, File 6000, Lieutenant-Colonel C.P. Van Ness (US Marine Corps), Exploding the Japanese Superman Myth, Undated, ?? spring 1943

${ }^{52}$ RG 165, War Department, G-2 Regional File, Box 2130, File 6000, Major-General O.W. Griswold, Commanding General, XIV Corps, Observer’s Report, 29 August 1943

${ }^{53}$ See RG 165, War Department, 'P' File, Box 214, Headquarters Army Ground Forces, Lessons of the Bougainville Campaign, Part 'E'.
} 
special service schools and published in War Department field manuals, proved sound. ${ }^{54}$ After the Salamaua operations, officers of the $162^{\text {nd }}$ infantry regiment almost unanimously agreed that the principles of tactics in jungle warfare were 'no different from those of open warfare'. ${ }^{55}$ The basic underlying concepts of US tactical methods remained unaltered. As late as June 1945, the G-3 of the Sixth Army maintained that the problems encountered in combat against the Japanese were 'fundamentally the same' as those that had been overcome in Europe. ${ }^{56}$ The ideas of leadership, small unit tactics, and the individual solution of technical and tactical problems had all been applied against the Wehrmacht, and were considered 'valuable' for defeating the Japanese. Unit leaders were left with the initiative to apply the basic doctrine of fighting a combined arms battle in the manner that they deemed to be most fit. The Sixth Army's operations section collated the recommendations put forward by its subordinate officers and summarized them in the operations reports, to provide commanders with a source of reference that could enable them to improve their practices. Towards the later stages of the conflict, as the Eighth and Tenth armies began to bear a larger brunt of the fighting, the Sixth Army needed to disseminate its knowledge with its counterparts. To facilitate the sharing of information between the army groups, the War Department's general staff set up a combat analysis section that was responsible for evaluating the salient features of the key engagements which American forces conducted.

Field commanders also had to bear in mind that the lessons learned at a particular operation could not always be applied universally, and that their methods had to be developed to suit changing circumstances. For example, prior to the Luzon operation, in anticipation that the battles would be conducted on open terrain, the $129^{\text {th }}$ infantry regiment ordered that a training area of a thousand square yards be blasted and cleared

\footnotetext{
${ }^{54}$ For examples, see RG 165, War Department, 'P' File, Box 214, Headquarters Army Ground Forces, Lessons of the Bougainville Campaign, Part 'E', and G-2 Regional File, Box 2153, File 6910, Report of the Commanding General, Buna Forces, Annex 2, G-2 Report

${ }^{55}$ RG 407, Records of the AGO, WWII Operations Reports, Box 10631, File 341-INF(162)-0.6, Headquarters $162^{\text {nd }}$ Infantry Regiment, $41^{\text {st }}$ Division, Notes on the Campaign by the $162^{\text {nd }}$ Infantry in New Guinea, 29 June to 12 September 1943

${ }^{56}$ RG 407, Records of the AGO, WWII Operations Reports, Box 9022, File 322-0.4, Assistant Chief of Staff, G-3, Sixth Army, Combat Notes, No.8, June 1945
} 
from the dense jungle. ${ }^{57}$ Although the Japanese proved slow to adjust their tactics, the Sixth Army warned that they were capable of introducing nominal changes, and commanders who used 'stereotyped' forms of attack could expect the enemy to be 'fully cognizant of their methods' ${ }^{58}$ Under such circumstances, success often came 'at a higher price than otherwise would be obtained'. The indications pointing to the IJA's ability to impose delay and attrition on their opponents meant that US Army officers had to continuously explore new techniques of engaging their opponent.

\section{Lessons of combat experience: general impressions of the IJA's weapons technology}

Following the US Army's initial victory at Buna in early 1943, the Japanese continued to demonstrate a certain level of tactical proficiency, and a categorical dismissal of their combat effectiveness was therefore premature. Assessments of the enemy's weapons technologies highlighted this aspect. Despite the problems arising from the IJA's perennial inadequacy of modern equipment and substandard methods of use, its infantry arm was often deployed skillfully. As a result, even at the closing stages of the conflict, the US army establishment considered the IJA to be a resilient enemy. The only source of comfort was that the Japanese possessed neither the resources nor skill to match the Allies.

US forces in the Pacific observed that the Japanese use of artillery was 'generally poor'. 59 Not only did the majority of divisions have an inadequate supply of munitions; the Japanese also appeared to not appreciate the importance of delivering massed fire, since they tended to order their batteries to work on dispersed areas rather than focus on a single objective. ${ }^{60}$ Concentrations of fire were weak in both duration and intensity, and

\footnotetext{
${ }^{57}$ RG 407, Records of the AGO, WWII Operations Reports, Box 10187, File 337-INF(129)$0.3 .0,129^{\text {th }}$ Infantry Regiment, $37^{\text {th }}$ Division, Training in Tank-Infantry Operations

${ }^{58}$ RG 407, Records of the AGO, WWII Operations Reports, Box 9022, File 322-0.4, Assistant Chief of Staff, G-3, Sixth Army, Combat Notes, No.7, May 1945

${ }^{59}$ RG 165, War Department, G-2 Regional File, Box 2146, File 6670, Headquarters, US Army Forces in the South Pacific Area, (USAFISPA), Information Bulletin No.21, 7 September 1943

${ }^{60}$ RG 319, Records of the Army Staff, 'P' Files, Library Branch, Box 2838, MIS, Intelligence Research Project, Weekly Summary, No.900, 2 December 1944
} 
the Japanese 'failed to achieve any adequate neutralization of the hostile targets' ${ }^{61}$

Armored units were in a similarly backward state. The most commonly encountered Japanese tank, the Model 2595, had a comparatively light armor plating by western standards, and at Tarawa, it proved 'highly vulnerable' to close-in attack by small weapons. ${ }^{62}$ The depression of the turret also left a 'dead space' extending over twenty feet in all directions, providing US marines with ample opportunities for sneaking up and disabling the tanks with sticky grenades and Molotov cocktails.

Yet, the IJA's deficiencies did not necessarily indicate that its forces were incompetent. Whereas western armies used mechanized forces to achieve mobility, the Japanese relied on the staying power of their infantry arm. The MIS acknowledged the practice as a logical one that did not entirely stem from flawed doctrine. In the Pacific theaters, rugged terrain and poor communications hindered the transport of heavy equipment. Oftentimes, the lack of modern weaponry was an asset, since it eased the IJA's logistical requirements and gave it more room for maneuver, allowing its 'well-trained and determined infantry' to 'operate to its best advantage'. ${ }^{63}$ The Japanese were also considered capable of developing weapons that were appropriate for the operations they engaged in, including anti-tank guns, armor piercing ammunition, and mines, thereby meeting the demands of the war 'to the best of [their] limited ability' ${ }^{64}$

Japanese methods of combating tanks were a telling example of their ability to compensate for their lack of modern weapons, by making good use of limited resources. During the Australian army's advance through New Guinea in late 1943, anti-tank guns were sited on high ground, and aimed at the main approaches, with guns concealed 'very

${ }^{61}$ US Army Military History Institute, Carlisle, PA, (MHI), War Department, MIS, Soldier's Guide to the Japanese army, Special Series No.27, November 1944, (hereafter, MIS, Soldier's Guide)

${ }^{62}$ RG 165, War Department, 'P' File, Box 1204, MIS, Intelligence Bulletin, Volume 2, No.10, Section I: 'Japanese tank tactics', June 1944

${ }^{63}$ RG 319, Records of the Army Staff, 'P' Files, Library Branch, Box 2096, Japanese Tactics, Lecture delivered at Research Unit, MIS, undated ?? spring 1944

${ }^{64}$ RG 494, MIDPAC, Box 5, G-2 Section, USAFISPA, Ground Information Bulletin, No.23, 19 May 1944 
well' in dense undergrowth. ${ }^{65}$ In subsequent encounters, infantry units operated with considerable skill against armored vehicles. Assault teams selected the most advantageous attack points, notably areas where tanks had to proceed through obstacles and thereby reduce their speed, including steep ravines, defiles, narrow roads, and thick vegetation. ${ }^{66}$ Each member had a special mission, which included placing an anti-tank mine under the tread, or throwing incendiary devices to force the crew to abandon the vehicle. Although the attacks often entailed a suicidal venture, the squads continued to pose obstacles for Allied tank crews until the closing stages of the conflict. As late as January 1945, the MIS warned that in jungle terrain, where tanks needed to move slowly, they were more easily approached and attacked by assault squads, particularly when supporting infantry troops failed to keep up with advancing tanks. ${ }^{67}$

Furthermore, while the Japanese could not equal the Allies in terms of equipment, improvements could not be ruled out. The IJA proved capable of introducing more effective artillery and armor, while bringing about better methods of their use, especially at the closing stages of the conflict. Captured documents showed an understanding of the need for mechanization and close infantry-armor cooperation. ${ }^{68}$ The MIS contended that more modern fighting methods were to be expected. The IJA's practice of studying German and Allied designs was likely to 'bring about important modifications' in the construction of armored vehicles. The possibilities of using tanks in wide encircling movements to cut Allied lines of communications and disorganize their rear areas also

${ }^{65}$ MHI, War Department, MIS, Military Reports of the United Nations, No.17, 'Australian employment of tanks in New Guinea', 15 April 1944

${ }^{66}$ RG 165, War Department, 'P' File, Box 1205, Headquarters South Pacific Base Command, Intelligence Bulletin No.12, 'Japanese special assault teams', 6 December 1944; also see RG 319, Records of the Army Staff, 'P' Files, Library Branch, Box 2858, MIS, Intelligence Research Project No.1899, Japanese Tank and Anti-tank Means and Methods, 9 June 1945.

${ }^{67}$ RG 165, War Department, 'P' File, Box 1204, MIS, Intelligence Bulletin, Volume 3, No.5, 'Be on the watch for tank hunters', January 1945

${ }^{68}$ US War Department, Handbook on Japanese Military Forces (Baton Rouge: Louisiana State UP, 1991), p.108. Document was originally published as Technical Manual, TM-E 30-480, 1 October 1944, (hereafter, War Department, Technical Manual, TM-E 30-480); also see MML, RG 3, GHQ Southwest Pacific Area, Box 121, ATIS, SWPA, Research Report No.116, Japanese Armored Forces, 16 March 1945; and Box 135, ATIS, SWPA, Enemy Publication, No.267, Antitank Warfare and Tank Warfare (printed handbook, dated November 1941), captured at Finschhafen, October 1943, translated 4 January 1945. 
could 'hardly be overlooked'. 69

The artillery arm showed a similar capacity for improvement. Japanese artillery played 'an important part' in slowing down the Sixth Army's advance through Luzon, and 'the excellence of the enemy survey was proved by the accuracy of fire' ${ }^{70}$ At Iwojima, the General Kurabayashi's garrison conducted the defense with 'unusual skill', and the employment of field guns was 'one of the outstanding features' of the campaign. ${ }^{71}$ The Japanese established an elaborate target designation system, and as a result, fire was delivered on the marines with a high degree of coherence. At Okinawa, General Ushijima's $32^{\text {nd }}$ Army possessed artillery in 'greater quantity, size and variety than had been available to them in any previous campaign'. ${ }^{72}$ The MIS alleged that the Japanese were able to deliver accurate fire only because they had registered it on fixed targets, and in a mobile battle, similar results were unlikely. ${ }^{73}$ Nevertheless, military intelligence conceded that the methods used were 'the most effective yet encountered' in the Pacific theater. The defending forces took advantage of the terrain features to obtain wide fields of fire. The Imperial Army's weaknesses in modern weapons and their tactical use did not provide sufficient cause to discredit its effectiveness. On the contrary, the appearance of improvements often precipitated caution.

\section{Defensive operations against the IJA}

When conducting attacks against Allied forces, the IJA proved adept at using its limited resources to get around the disadvantages arising from its shortage of fire support. The main threat was posed by the infantry arm's ability to execute skillful maneuvers and cause significant damage for inadequately protected forces. In order to properly defend

\footnotetext{
${ }^{69}$ RG 226, OSS, Research and Analysis Branch Divisions, Intelligence Reports, Box 1281, File 112908, MIS, Special Series No.26, Japanese Tanks and Tank Tactics, 15 November 1944

${ }^{70}$ RG 495, US Army Forces, Western Pacific, Box 120, Records of the Pacific Warfare Board, Battle Experiences against the Japanese, Report No.21, 21 July 1945, (hereafter, Pacific Warfare Board, Battle Experiences, Report No., date); also see Smith, Triumph, p.148.

${ }^{71}$ RG 165, War Department, 'P' File, Box 2314, MIS, Tactical and Technical Trends, No.59, 'Japanese artillery tactics at Iwojima', June 1945

${ }^{72}$ Appleman, Okinawa, p.91

${ }^{73}$ RG 165, War Department, 'P' File, Box 1204, MIS, Intelligence Bulletin, Volume 3, No.12, 'Artillery on Okinawa', August 1945
} 
their positions, the US Army needed to develop measures that relied on a combination of firepower and tactical flair. Troops needed to pinpoint the location of enemy units, and neutralize them with supporting fire and coordinated counterattacks carried out by infantrymen.

US military intelligence noted how the IJA's doctrine placed emphasis on 'the inherent superiority of the offensive', and field service regulations stipulated that attacks were to be carried out 'resolutely'. ${ }^{74}$ At all stages, Japanese planning was meticulous, and paid attention to detail. Prior to the attack, the size and layout of the Allied defenses were ascertained. Reconnaissance was 'well emphasized', and this was one of the primary tasks assigned to the leading elements. ${ }^{75}$ Once the opposing force was located, forward units attempted to infiltrate gaps in the defense.

Infiltration movements were carried out by special assault teams, who formed an 'integral part' of each battalion. ${ }^{76}$ Their main task was to breach wire entanglements, and also deal with small teams of Allied troops who attempted to oppose the attack. They then fired automatic weapons to give the impression that the Japanese had encircled the position. In jungle country, where visibility was at a minimum, and US forces faced difficulties in maintaining close contact with friendly troops, the IJA's use of such tactics was disconcerting. Infiltration units were also assigned to harass Allied lines of communication and destroy their supply depots. Because the attacks were carried out against opponents with overwhelmingly superior fire power, they turned out to be suicide ventures. Yet, even on suicide missions, Japanese troops were expected to carefully consider their objectives. ${ }^{77}$ The attacks were planned to exact the 'maximum toll' on Allied forces, and carried out at the 'most suitable times' to secure this aim. ${ }^{78}$

\footnotetext{
${ }^{74}$ War Department, Technical Manual, TM-E 30-480, p.85

${ }^{75}$ RG 319, Records of the Army Staff, 'P' Files, Library Branch, Box 2096, Japanese Tactics, Lecture delivered at Research Unit, MIS, undated ?? spring 1944

${ }^{76}$ RG 165, War Department, 'P' File, Box 1204, MIS, Intelligence Bulletin, Volume 2, No.11, 'Small-unit tactics used by the Japanese', July 1944

${ }^{77}$ RG 319, Records of the Army Staff, 'P' Files, Library Branch, Box 2840, MIS, Intelligence Research Project No.900, Weekly Summary, 17 February 1945

${ }^{78}$ RG 319, Records of the Army Staff, 'P' Files, Library Branch, Box 2841, MIS, Intelligence
} 
In the approach march, the primary emphasis was on surprise and mobility. Encirclement and flanking movements were the preferred methods, since they allowed commanders to utilize the ability of their infantry units to move quickly through the jungle. The attacking force moved into an assembly area, and advanced to a point several miles from the Allied front line, where the final development of units was made. Heavy weapons were emplaced to assist the advance. Attacks were most often conducted on undefended flanks, and the Japanese used diversionary moves in a direction different from that taken by the main force. ${ }^{79}$ The meeting engagement, or the final encounter with enemy forces, was the 'foundation of combat training', with 'official regulations giving more space to it than any other form of combat'. ${ }^{80}$ Speed was stressed, and bayonet charges were the favorite method of closing in with the enemy, since they enabled soldiers to realize their 'assumed superiority in hand-to-hand fighting'. As the Pacific War progressed, Japanese offensive actions declined in efficiency, and proved unsuccessful against opponents with superior firepower and tactical skill. Frontal attacks, often conducted with inadequate supporting arms, were common. On other occasions, the Japanese resorted to piecemeal actions instead of coordinated attacks.

Nevertheless, the IJA's methods could be downplayed only when the US Army devised suitable defense measures. The development of adequate methods often entailed a process of trial and error. In the jungle, where visibility was restricted by vegetation and terrain, and enemy forces could bypass even the narrowest of undefended or unobserved areas, the traditional method of establishing isolated look-out posts was 'inadvisable' ${ }^{81}$ In order to secure their positions, US forces needed to construct a perimeter defense consisting of mutually supporting foxholes, and thereafter become acquainted with their surroundings, so as not to be caught off guard by the appearance of enemy forces. At

Research Project No.900, Weekly Summary, 21 April 1945

${ }^{79}$ RG 165, War Department, 'P' File, Box 1204, MIS, Intelligence Bulletin, Volume 3, No.5, 'Japanese combat tactics', January 1945

${ }^{80}$ War Department, Technical Manual, TM-E 30-480, p.86

${ }^{81}$ RG 165, War Department, 'P' File, Box 570, MIS, Combat Lessons, No.1, 'Security in the Jungle', derived from Report of Commanding General, $43^{\text {rd }}$ Division, New Georgia campaign, undated, ?? early 1944 
Bougainville, the Japanese proved 'hardly capable of a successful offensive against a perimeter as stout and as well organized as that set up by the [US] forces'. ${ }^{82}$ Enemy forces encountered stronger resistance than they expected, but proved 'unable to make the emphatic changes necessary in [their plans]', and their assaults were best described as 'determined but unoriginal' ${ }^{83}$ Yet, the halting of the enemy assault was attributed to the fact that the XIV Corps was fully prepared to cope with it. Captured documents and POWs revealed the enemy plan for a large scale attack, and the defending forces conducted a vigorous patrol which confirmed the information, thereby enabling them to know almost the exact date and hour of the operation.

The Americans also needed to deal with Japanese attacks at night, when the cover of darkness complicated the task of target identification. Troops needed to remain alert, with patrols setting up ambushes. Firing slits were provided on at least three sides of the position, with automatic fire 'carefully sited so as to have a minimum of dead space'. ${ }^{84}$ By the time of the Okinawa operation, the XXIV Corps found that 'the most efficient and least costly way to kill Japanese [was] to let them attack at night'. ${ }^{85}$ Enemy troops conducted repeated attacks, only to be mowed down by automatic fire. Even then, observers noted the substantial effort undertaken to provide an adequate defense. Tripwires were set up in front of outposts to provide warnings of the attack, and perimeter defenses were employed by 'all installations including the Corps command post'. Apprehensions were dispelled only insofar as US forces proved capable of dealing with the elements they faced. Information pointing to the weaknesses of Japanese tactics

${ }^{82}$ RG 407, Records of the AGO, WWII Operations Reports, Box 10192, File 337-INF(129)1$0.1,129^{\text {th }}$ Infantry Regiment, $37^{\text {th }}$ Division, Bougainville, Solomon Islands, November 13,1943 to April 30, 1944, Section III, Intelligence Report

${ }^{83}$ RG 407, Records of the AGO, WWII Operations Reports, Box 4014, File 214-0.3, XIV Corps, Summary of Operations in the Bougainville area, 15 December 1943 to 21 November 1944, Section 1: G-2 Intelligence Summary

${ }^{84}$ RG 407, Records of the AGO, WWII Operations Reports, Box 10234, File 337-INF(145)-0.4, Headquarters $148^{\text {th }}$ Infantry Regiment, $37^{\text {th }}$ Division, Conclusions and Lessons from the Bougainville Operation, 24 April 1944

${ }^{85}$ RG 165, War Department, 'P' File, Box 879, Combat Analysis Section, Operations Division, Extracts from Operations Reports on Fighting the Japanese at Night, 29 June 1945, derived from report by Army Ground Forces Observer, Lieutenant-Colonel Robert C Williams (Infantry), 29 June 1945 
provided reassurances insofar as it provided combat personnel with hints on the various elements they could exploit. Nevertheless, concerns over the IJA's ability to put up a contest were not alleviated unless the Americans developed the skills and resources necessary to defeat their opponent.

\section{Offensive operations against the IJA}

The Imperial Army's proficiency in defending its positions against the Allies astounded US intelligence staffs and military personnel alike. As was the case in all of their operations, enemy forces were adept at offsetting their technological and material superiority by making an efficient use of their resources. Positions were made to withstand the effects of bombardment, while at the same time imposing delay and attrition on the attackers. Enemy troops also continued to hold an almost unbroken willingness to fight to until they were killed.

US Army commanders learned to develop tactics which called for the deployment of substantial amounts of heavy weapons, including artillery, mortars, and armor. Overwhelming firepower was also effective for neutralizing enemy forces who were not sufficiently equipped. However, foot soldiers were needed to perform a number of vital tasks. The IJA's skilful use of its infantry arm, coupled with the Japanese soldier's practice of holding his positions to the last man and round, meant that American troops had to maneuver themselves to physically occupy enemy positions and mop up the remnants of resistance, without incurring excessive casualties.

In defensive operations, the IJA's overriding objective was to 'equalize' the initial disparity between Japanese and Allied forces sufficiently so that the IJA could regain the initiative. ${ }^{86}$ Military traditions viewed defensive operations as 'inglorious'; hence they were treated as temporary measures to halt hostile forces until counteroffensives could be launched. ${ }^{87}$ Japanese defenses were rarely static, and even when forced on the defensive,

\footnotetext{
${ }^{86}$ Military Intelligence Training Center, Japanese Combat Methods

${ }^{87}$ RG 165, War Department, 'P' File, Box 1203, MIS, Intelligence Bulletin, Volume 2, No.6, Section I: 'Notes on Japanese jungle defense', February 1944
} 
officers had 'the return to the offensive always uppermost in their minds'. ${ }^{88}$ Counterattacks were launched when the Japanese were driven out of a position or compelled to give up terrain that was vital for protecting their supply lines. The moves were accompanied by 'wild firing of machine guns and rifles', and their effectiveness depended on 'the speed and surprise with which [they were] made'. ${ }^{89}$

The dangers posed by counter-attacks were dismissed when they resulted in mass casualties for the Japanese, without a corresponding loss for the Allies. In the Admiralty islands, enemy forces conducted a series of isolated counter-attacks made by small bodies of troops which failed to break the advance of US troops, and their casualties 'were out of all proportion to the results obtained' ${ }^{90}$ Yet, the potential effects remained a concern. At Luzon, the Sixth Army had to be provided with constant artillery and mortar support to neutralize enemy movements, while infantry advances were planned so that troops stayed within range of fire cover. ${ }^{91}$

The IJA was also thorough in preparing its field fortifications, and its practices conformed 'closely to the standards of other armies'. ${ }^{92}$ Bunkers were constructed to provide protection in depth and width, with installations made to provide an all-around defense. The IJA relied on three main methods, each posing a distinct challenge. Firstly, the construction of fortifications was adjusted in accordance with the landscape of the locality, and geared towards making the maximum use of natural obstacles. This practice made it difficult for Allied forces to reach within close proximity of enemy defenses. In New Guinea, the Japanese tended to choose positions which were flanked on one or both sides by obstacles such as rivers, creeks, steep hills, and mountains. ${ }^{93}$ In hilly country, the

\footnotetext{
${ }^{88}$ War Department, Technical Manual, TM-E 30-480, pp.102-3

${ }^{89}$ RG 165, War Department, 'P' File, Box 1204, MIS, Intelligence Bulletin, Volume 2, No.9, Section II: 'Japanese defensive tactics', May 1944

${ }^{90}$ RG 165, War Department, 'P' File, Box 1204, MIS, Intelligence Bulletin, Volume 3, No.3, 'In the Admiralties: fanatic Japanese rushes withered by steady US defense', November 1944; also see Krueger, Down Under, p.54

${ }^{91}$ Pacific Warfare Board, Battle Experiences, Report No.13, 4 July 1945; also see Smith, Triumph, p.205

${ }^{92}$ MIS, Soldier's Guide

${ }^{93}$ RG 165, War Department, 'P' File, Box 1203, MIS, Intelligence Bulletin, Volume 1, No.12,
} 
main positions were prepared on the reverse slopes. Machine gun posts and artillery were sited on hilltops to obtain wide fields of fire. The Japanese also used vegetation to camouflage their positions, to the point where they were virtually invisible to aerial spotters and ground patrols. Soldiers of the $43^{\text {rd }}$ division remarked that Japanese positions were 'easier to smell than see'. ${ }^{94}$

The use of caves was also common. Because the Pacific islands consisted of coral and volcanic formations, the Japanese had ample opportunities to place themselves in natural dugouts. The practice enabled the defenders to develop positions affording maximum protection, without requiring substantial efforts to build an elaborate system of man-made fortifications. At Biak, Japanese positions consisted of three large caves connected by a series of tunnels, with enough room to shelter a thousand men. In order to reach the main defenses, US forces had to overcome the resistance offered by the enemy in hundreds of smaller caves located along the coral ridges. ${ }^{95}$ The defenses were described as 'one of the most amazing' installations seen in the Southwest Pacific. ${ }^{96}$ By the time of the Luzon campaign, the Sixth Army had been prepared by previous operations to expect the Japanese to resort to cave warfare; nevertheless, the defensive tactic was exploited to such an extent as to constitute a 'major intelligence problem' ${ }^{97}$ The IJA's attempts to improve his defense of underground positions required a careful study, followed by a prompt dissemination of evaluated information to combat troops.

The most notable example of the IJA's skill at utilizing cave defenses arose at Okinawa. The Japanese considered the island to be a part of their home territory, and owing to its strategic importance, the defenses were more elaborate than previously encountered. The $32^{\text {nd }}$ Army concentrated its effort in the Shuri sector, a mountainous area in the center of

Section III: ‘Defense Techniques’, August 1943

${ }^{94}$ Miller, Cartwheel, p.133

${ }^{95}$ For a recollection, see Krueger, Down Under, p.104.

${ }^{96}$ RG 165, War Department, 'P' File, Box 1204, MIS, Intelligence Bulletin, Volume 3, No.3, 'Japanese cave defenses on Biak island', November 1944

${ }^{97}$ RG 407, Records of the AGO, WWII Operations Reports, Box 1955, File 106-0.3, Sixth Army, Report of the Luzon Campaign, 9 January to 30 June 1945, Annex: Enemy Capabilities Report of the Assistant Chief of Staff, G-2 
the island, where it constructed a series of concentric positions arranged around the contours of the area, with caves, emplacements, blockhouses and pill-boxes built into the hills, all connected by elaborate underground tunnels. Machine guns were sited to cover all avenues of approach. The Japanese were credited for making 'excellent' use of the terrain, which lent 'itself well to anti-tank defense'. ${ }^{98}$ A large number of tunnels were dug into the hills as anti-tank emplacements, and placed to cover the likely approaches. Entrances to caves were covered by machine gun and mortar fire, with weapons sited to provide mutual support. The use of reverse slopes added to the difficulty of neutralizing the cave entrances by artillery bombardment. ${ }^{99}$ The MIS opined that the Japanese had not remained 'static' in their tactics'. ${ }^{100}$ US intelligence paid due heed to the IJA's ability to impede Allied operations until the closing stages of the conflict.

The neutralization of cave defenses required ingenuity, and army personnel had to devise creative ways of 'holing out' the Japanese until the closing stages of the conflict. Aerial bombardment and strafing had 'little physical effect' upon deep cave structures or defending personnel. ${ }^{101}$ At Biak, and again at Angaur, in the Palaus, the use of gasoline, poured into the windward entrances and ignited by grenades, tended to do the job of exhausting the defenders' oxygen supplies and destroying their ammunition. ${ }^{102}$ Flamethrowers were also useful, owing to their ability to follow the curves of a cave. ${ }^{103}$

\footnotetext{
${ }^{98}$ RG 319, Records of the Army Staff, 'P' Files, Library Branch, Box 2842, MIS, Intelligence Research Project No.900, Weekly Summary, 23 June 1945

99 RG 165, War Department, 'P' File, Box 1206, G-2 Section, USAFPOA, Intelligence Bulletin, No.18, 15 June 1945

${ }^{100}$ RG 165, War Department, 'P' File, Box 1301, MIS, Bulletin No.9, Japanese Army: organization, equipment and tactics, 7 March 1945

${ }^{101}$ RG 165, War Department, 'P' File, Box 879, General Staff, Combat Analysis Section, Operations Division, Extracts from Operations Reports on Reduction of Japanese Cave-Type Fortifications, US Army Forces, Far East (USAFFE) Board, Report No.1, 30 July 1944, 22 May 1945. (hereafter, Combat Analysis Section, Reduction of Japanese Cave-Type Fortifications, title of original report); also see Smith, Approach, pp.306-7.

${ }^{102}$ RG 165, War Department, 'P' File, Box 570, MIS, Combat Lessons, No.8, 'On Killing Japanese', undated, ?? spring 1945; also see RG 165, War Department, 'P’ File, Box 1301, MIS, Japanese Army: organization, equipment and tactics, Bulletin No.2, 17 January 1945; for secondary accounts, see Smith, Approach, pp.374-75; Eichelberger, Jungle Road, pp.178-81.

103 Combat Analysis Section, Reduction of Japanese Cave-Type Fortifications, Report by USAFFE Board, 17 July 1944
} 
During the Luzon campaign, US forces used a combination of artillery and air bombardment to force the Japanese to retire to the inner recesses while US troops approached. ${ }^{104}$ When artillery fire was lifted, the Japanese were kept back in the tunnels by the use of hand grenades and flame throwers directed against the entrances. The effectiveness of the procedure was illustrated by a report from one division that claimed to have blown up over 400 outlets of caves without suffering a single casualty. At Okinawa, the firepower of ground forces was further augmented by armored units who covered the infantry advance, and laid direct fire on the cave mouth. ${ }^{105}$ When enemy forces appeared to have retreated to the interior, the entrances to each cave position were systematically sealed by smoke, and the Japanese left to suffocate.

The use of natural cover was augmented by a second notable characteristic in the IJA's defensive methods, namely the construction of fortifications that could withstand bombardment. At the Munda airfield area, pill-boxes sometimes withstood direct attack by light tanks with 37-mm guns, as well as 25-pound shells and 81-mm mortar projectiles. ${ }^{106}$ In New Guinea, bunkers were positioned to provide close mutual support, often no more than five yards apart, with a second line immediately to the rear, covering the gaps. ${ }^{107}$ In other instances, fortifications were designed to provide wide fields of fire, with protection from bombardment being a secondary concern. At New Georgia, machine gun outposts were 'found considerably in advance of main positions', so they could place enfilade fire on the advancing parties. ${ }^{108}$

The third characteristic of Japanese defensive tactics was encountered when Allied

\footnotetext{
${ }^{104}$ RG 165, War Department, 'P' File, Box 2314, MIS, Tactical and Technical Trends, No.58, 'Japanese continue extensive use of cave fortifications', May 1945.

${ }^{105}$ RG 165, War Department, 'P' File, Box 1206, G-2, USAFPOA, Intelligence Bulletin No.18, 'Japanese combat methods on Okinawa (from Headquarters Tenth Army, Weekly Intelligence Summary, No.1), 15 June 1945

${ }^{106}$ RG 165, War Department, 'P' File, Box 2314, MIS, Tactical and Technical Trends, No.44, 'Japanese defense at Munda', 1 March 1944; also see Miller, Cartwheel, pp.132, 148.

${ }^{107}$ RG 165, War Department, 'P' File, Box 2313, MIS, Tactical and Technical Trends, No.31, 'Japanese conduct of the defense', 12 August 1943

${ }^{108}$ RG 494, MIDPAC, Box 5, G-2 USAFISPA, Ground Information Bulletin, No.8, 4 February 1944
} 
infantry units conducted their final assault. Enemy troops showed their propensity to force close-range battles. A common practice was to inflict surprise on the approaching troops, by holding fire until they were within proximity of the positions. Ruses were also used to catch US forces off guard. At New Britain, Allied troops were allowed to pass Japanese defense positions, and when the defenders started firing, the attackers found themselves 'cut off without the possibility of retreat'. ${ }^{109}$ The $21^{\text {st }}$ infantry regiment noted how the Japanese forces defending Breakneck Ridge at Leyte conducted well-organized counterattacks, and rarely made suicide charges or sacrificed their troops needlessly. Enemy forces were credited for observing 'known tactical principles'. ${ }^{110}$ US army commanders learned through experience that the IJA's lack of firepower did not render it an easy opponent. On the contrary, under certain conditions, the Japanese had particular strengths.

For army commanders, the information which pointed to the IJA's skill in preparing and protecting its positions provided a telltale sign that US forces needed to undertake a number of measures to neutralize their opponent's capacity to resist. The first essential measure was to provide adequate firepower so that the defenses could be softened, to the point where infantry units could advance without incurring high casualties. The provision of close air support was problematic. At Bougainville, the Japanese exhibited 'great skill' in using the jungle vegetation to hamper aerial observation of their routes of march, assembly areas, and general operations. ${ }^{111}$ Air support was seldom used during the Cartwheel campaign, partly because enemy positions could rarely be identified by spotters in observation planes or by air liaison parties on the ground. ${ }^{112}$

Air support also tended to cause damage to friendly forces, and was efficient only when US forces managed to establish an adequate level of inter-service cooperation. The Sixth

\footnotetext{
${ }^{109}$ RG 165, War Department, 'P' File, Box 1204, MIS, Intelligence Bulletin, Volume 3, No.4, 'They learned by experience', December 1944

${ }^{110}$ Cannon, Leyte, p.251

${ }^{111}$ RG 407, Records of the AGO, WWII Operations Reports, Box 10037, File 337.2, 37 ${ }^{\text {th }}$ Infantry Division, Lessons of Bougainville campaign, 18 July 1944

112 Miller, Cartwheel, p.142
} 
Army's advance in northern Luzon was conducted against a 'determined enemy occupying strongly fortified positions on most difficult terrain', but the campaign proceeded with few hold-ups, largely because it was 'whole-heartedly and ably supported by $5^{\text {th }}$ Air Force'. ${ }^{113}$

Field artillery proved more useful for dealing with Japanese forces in jungle terrain, because they were able to operate at closer ranges than air forces. In order to operate effectively, artillery units needed to synchronize their fire so that advancing the infantry could be covered. At Guadalcanal, field guns proved 'highly effective in destroying stubborn enemy resistance', mainly because liaison officers provided intelligence that aided the adjustment of artillery so they could hit smaller targets such as machine guns, mortars, and dug-in pockets of resistance. ${ }^{114} \mathrm{~A}$ report on the use of artillery in closecountry warfare, prepared by the British general headquarters in India, explained how, owing to the durability which often characterized Japanese defense positions, fire had to be concentrated. ${ }^{115}$ Infantry had to keep as close to the barrage as possible; otherwise, the defenders were likely to emerge from their positions when the fire lifted, and inflict substantial casualties on the approaching infantry.

However, the lessons of initial combat experiences were not the only ingredient necessary to perfect the performance of US forces. Equally important for success was to learn through trial and error. In many cases, problems arose when the infantry 'looked for results entirely out of proportion to the artillery's capabilities', expecting the guns to cover a larger front than they could. ${ }^{116}$ Advancing troops needed to be 'impressed with the true capabilities and limitations' of their supporting arms. Towards the closing stages of the war, the US army's use of artillery showed a significantly improved understanding

\footnotetext{
${ }^{113}$ MML, RG 30, Papers of Richard K Sutherland, Box 1, Folder 7, Signals Corps, US Army, to Advance Echelon, GHQ SWPA, 8 April 1945

${ }^{114}$ MHI, War Department, MIS, Military Reports of the United Nations, No.8, 'Employment of field artillery on Guadalcanal', 15 July 1943

${ }^{115}$ MHI, War Department, MIS, Military Reports of the United Nations, No.11, 'Artillery in the Jungle', 15 October 1943

${ }^{116}$ RG 407, Records of the AGO, WWII Operations Reports, Box 10037, File 337.2, $37^{\text {th }}$ Infantry Division, Lessons of Bougainville campaign, 18 July 1944
} 
of the need to coordinate supporting fire with infantry movements. At Okinawa, aside from close air support, the most successful use of firepower was the fire of Allied mortars and artillery, placed on reverse slopes and on suspected enemy mortar or artillery positions. ${ }^{117}$ Still the operation was treated as another example of how the resilience of Japanese defenses required the US army to employ weapons that held all the necessary qualities of accuracy, fire power weight and mobility.

Armored units proved useful for providing immediate support in areas where enemy troops were known to be holding up an advance. Nevertheless, tanks had to operate in close conjunction with infantry units One of the key lessons to emerge from the New Guinea operation was that tanks had to advance at a rate regulated by that of the main infantry body. ${ }^{118}$ Protective parties had to be assigned to each tank, and be ready to take instant action against anti-tank teams. Tank crews also had to make good use of artillery support, which was more capable of reducing the defenses and paving the way for the advance. Last but not least, tanks needed to avoid frontal assaults on Japanese positions or coming within close range of pill-boxes.

When US forces succeeded in overcoming Japanese defenses by effecting an adequate level of tank-infantry cooperation, after-action reports still reinforced the need to employ proper tactics. The Sixth Army's G-2 section recalled how, during the Leyte operation, tank attacks had to be guarded in the front, flanks and rear by riflemen, in order to prevent suicide attacks by the Japanese. ${ }^{119}$ The Okinawa operation showed how the tactical employment of armor was sound. Nevertheless, US forces needed a to carry out a painstaking effort to ensure that their methods were suitable. As US forces prepared to operate in the home islands, an adjustment of weapons, and their methods of use were likely to become essential in order to cope with stronger defenses The XXIV Corps

\footnotetext{
${ }^{117}$ MHI, Papers of Andrew D Bruce, $77^{\text {th }}$ Infantry Division, Operation Report on Iceberg: Phase I, G-3 Comments and Recommendations

${ }^{118}$ MHI, War Department, MIS, Military Reports of the United Nations, No.6, 'Notes on the employment of tanks in New Guinea', 15 May 1943

${ }^{119}$ RG 165, War Department, 'P' File, Box 1206, G-2, USAFPOA, Intelligence Bulletin, No.11, 'Notes on the Japanese defense of Breakneck Ridge', 9 March 1945; also see Cannon, Leyte, pp.211, 241
} 
recommended, 'a complete restudy of supporting armor for future action against the Japanese in his homeland is in order' ${ }^{120}$ The M-5A-1 tank was considered too light, and needed to be replaced with the heavier M-24. The obstacles posed by Japanese defenses compelled US army officials to regularly reassess the effectiveness of their own weapons and tactics.

While supporting arms played an important role in neutralizing Japanese defenses, infantry units also needed to take on a large part of the task. Foot soldiers performed a number of essential duties, the first of which was to reconnoiter the location and layout of enemy positions, so that fire support could be delivered at the right places. Because the Japanese were highly adept at using natural cover to conceal their pill-boxes, 'prime consideration' had to be given to target designation. ${ }^{121}$ A prior knowledge of the targets was essential in order to enable their forces to effectively deploy their overwhelming firepower. Infantry units were needed to gather intelligence mainly because aerial reconnaissance in areas such as New Guinea often did not provide a good picture of the target area. At Cape Gloucester, aerial photographs were described as 'excellent', but they 'simply did not show what was hidden by the jungle'. ${ }^{122}$ Added to the problems caused by enemy camouflage was the shortage of aircraft with adequate range, coupled with bad weather, and the absence of discernible landmarks in the dense jungle. During the early part of 1944, only half of the photographic reconnaissance missions were successful, prompting Sutherland to complain to George Kenney, 'in no instance has photography been submitted as originally requested'. ${ }^{123}$

Obtaining proper information on Japanese positions was not an easy task for ground

\footnotetext{
${ }^{120}$ RG 127, Records of the US Marine Corps, World War II Operations, Geographic Area Files, Box 209, XXIV Corps, Action Report, Ryukyus, 1 April to 30 June 1945 (hereafter, XXIV Corps, Ryukyus, 1 April to 30 June 1945)

${ }^{121}$ RG 407, Records of the AGO, WWII Operations Reports, Box 4631, File 214-3.14, Headquarters XIV Corps, Tank-Infantry-Engineer Team in Jungle Operations, Annex D to Report on Lessons learned during Bougainville operation, 28 April 1944

${ }^{122}$ Krueger, Down Under, p.27

${ }^{123}$ Taafe, Jungle War, p.39; also see MHI, Papers of George Decker, Sixth Army, 1943-45, Major-General C.P. Hall to Lieutenant-General Krueger, 8 July 1944.
} 
troops. The limited visibility in the jungle presented only a 'worms-eye view'. ${ }^{124}$ The 'exceedingly effective and clever camouflage' challenged even the best trained observers. Reconnaissance patrol teams also needed to approach enemy lines without being detected. ${ }^{125}$ Visual contact had to be maintained at all times. A thorough survey of the ground was necessary to ensure that information on Japanese dispositions was complete.

As the Allied campaigns progressed, US troops showed a steady improvement in their methods of ground reconnaissance, largely due to a rigorous training program. In 1943, Krueger established a special center for the Alamo Scouts, an elite reconnaissance unit. ${ }^{126}$ The six-week course included instruction in map reading, scouting and patrolling. The scouts proved to be of 'inestimable value to the Sixth Army'. Commenting on the Hollandia operation, army officials contended that the 'intensive training in scouting and patrolling paid dividends in combat', and this was 'clearly proved by the extremely small percentage' of casualties. ${ }^{127}$

The second crucial task which infantry units had was to occupy the ground and secure it against counterattacks. Units who did not have extensive experience faced difficulties. In situations where troops did not attempt to secure their objectives at the earliest practicable opportunity, US forces incurred losses that could otherwise be avoided. At Leyte, advancing units frequently fell back and called for supporting fire if they met anything more than minor resistance, and the 'natural reluctance' of the American infantryman to engage the enemy in close quarters had yet to be overcome. ${ }^{128}$ General Krueger insisted that the infantry needed to be prepared to close in immediately after the cessation of artillery fire. Any delay was more likely to give the Japanese time to regroup and consolidate, thus nullifying the effects of the preparatory fires. At Mindanao, the

\footnotetext{
${ }^{124}$ XIV Corps, Informal Report on Combat Operations

${ }^{125}$ RG 494, MIDPAC, Box 5, G-2 USAFISPA, Ground Information Bulletin, No.7, 28 January 1944; Pacific Warfare Board, Battle Experiences, Report No.17, obtained from Americal Division, Bougainville, 10 July 1945

${ }^{126}$ Leary, 'Walter Krueger', p.69; Krueger, Down Under, p.29

${ }^{127}$ RG 407, Records of the AGO, WWII Operations Reports, Box 7673, File 324-0.4, Headquarters US Forces, Lessons Learned by Tanahmerah Landing Force in Hollandia Operation, 10 June 1944

${ }^{128}$ Cannon, Leyte, p.245-46
} 
$152^{\text {nd }}$ regiment's 'lack of aggressiveness' allowed the Japanese to bring up reinforcements, causing 'additional time lost and casualties in reaching the objective'. ${ }^{129}$ The $149^{\text {th }}$ regiment concluded that infantry units needed to engage in hand-to-hand combat, rather than 'putting all their faith in the ability of the artillery to take out resistance'.

Nevertheless, most infantry units showed an increased ability to bear the brunt of the fighting. Individual training was carried out so that foot soldiers were 'thoroughly proficient' with their weapons. ${ }^{130}$ In New Guinea, troops relied 'first and foremost' on hand-held equipment. ${ }^{131}$ The Browning automatic rifle was particularly effective in repelling Japanese attacks, while the .30 caliber light machine gun had enough range to keep the enemy troops trapped in their positions. The flamethrower came 'into its own' as an offensive weapon, and all regiments employed it against enemy positions, both in the assault and mopping up operations. ${ }^{132}$ The $81 \mathrm{~mm}$ mortar also proved useful for driving Japanese soldiers out of their pill-boxes, whence they became targets for rifle and machine gun fire. ${ }^{133}$

Combat experience showed that operations against the IJA in jungle terrain were most effective when conducted by small-unit formations, no larger than a squadron. The rugged terrain did not permit the movement of massed forces. Major-General William Gill, commanding the $32^{\text {nd }}$ Division, recalled that small-unit scouts were 'the only ones that could get anywhere' because his forces had to 'cut [their] way through swamps and the enemy was there' to stop their movements. ${ }^{134}$ Japanese positions were also designed to deliver large amounts of fire against the most accessible avenues of approach, thus requiring US forces to conduct flanking attacks rather than a frontal assault. A substantial

\footnotetext{
${ }^{129}$ MHI, Papers of George Decker, (Sixth Army), 1943-45, Major C.P. Hall, Headquarters XI Corps, to Major-General H.L.C. Jones, Commanding General, $38^{\text {th }}$ Infantry Division, Operations during 31 January to 2 February inclusive, 4 February 1945

${ }^{130}$ RG 407, Records of the AGO, WWII Operations Reports, Box 8134, File 325-INF (27)-3.13, Headquarters, $27^{\text {th }}$ Infantry Division, Training Memorandum, 1 March 1944

${ }^{131}$ Taafe, Jungle War, p.114

${ }^{132}$ Miller, Cartwheel, p.160

${ }^{133}$ Ibid., p.161

${ }^{134}$ Gill, Always a Commander, p.57
} 
effort was undertaken to develop teamwork at the squadron and platoon level. Infantrymen also received a comprehensive instruction in the employment of demolition devices. The success of the Munda campaign was attributed to the skilful use of platoons, supported by heavy artillery concentrations and accompanied at all times by $81 \mathrm{~mm}$ mortar fire. ${ }^{135}$ At Kwajalein, small teams of infantry soldiers and engineers reduced enemy pill-boxes and blockhouses by breaching the walls of the positions with explosives, and thereafter destroying the enemy with grenades or flame throwers. ${ }^{136}$ During the Aitape operations in summer 1944, the Ted Force managed to force the $18^{\text {th }}$ Army to withdraw from the Driniumor river, with only a two percent casualty rate arising from enemy action. ${ }^{137}$ The success was cited as 'a tribute to the leadership within Ted Force and to the teamwork of all ranks'.

In a number of cases, infantry had little choice apart from neutralizing the positions themselves. During the advance into the Ormoc Valley, the Japanese built defenses at such high altitudes on the ridges that effective fire could not be placed on them. ${ }^{138}$ The steepness of the terrain and denseness of tree growth meant that 'artillery and mortar fire could not be used to full advantage' ${ }^{139}$ Yet, the Sixth Army succeeded in occupying the main roads and preventing the arrival of reinforcements. The operation was attributed as an example of how 'the calm assurance of leaders', coupled with the 'cold courage and grim tenacity of the individual infantryman', enabled US troops to overcome even the seemingly most formidable obstacles. ${ }^{140}$ By the time of the Okinawa operations, the doctrine followed by infantry units was credited for being 'entirely sound'. ${ }^{141}$ The XXIV Corps concluded that the battle was won by the close-knit cooperation and teamwork of small infantry units, 'closely integrated with their close-supporting weapons'. While air

\footnotetext{
${ }^{135}$ XIV Corps, Informal Report on Combat Operations

${ }^{136}$ RG 407, Records of the AGO, WWII Operations Reports, Box 8339, File 327-3.01, 27 ${ }^{\text {th }}$ Infantry Division, Lessons Learned for mission similar to $7^{\text {th }}$ Division's mission at Kwajalein

${ }^{137}$ Smith, Approach, p.200

${ }^{138}$ Ibid., p.267

${ }^{139}$ Ibid., p.328

${ }^{140}$ RG 407, Records of the AGO, WWII Operations Reports, Box 9022, File 322-0.4, Assistant Chief of Staff, G-3, Sixth Army, Combat Notes, No.6, 20 April 1945

${ }^{141}$ XXIV Corps, Ryukyus, 1 April to 30 June 1945
} 
support, naval gunfire, and artillery were used to the fullest, bombardment was often effective for simply setting up the correct conditions for the advance. Japanese forces were not completely destroyed, and in order to neutralize the surviving elements, close-in assaults, conducted by infantrymen were the rule rather than the exception. Thus, infantry units were, as Krueger once described them, 'the arm of final combat'. ${ }^{142}$ US army commanders learned through experience that supporting weapons were merely one of a myriad of necessities.

\section{Conclusion}

US assessments on the IJA between the conclusion of the Buna campaign in January 1943 and Japan's surrender in August 1945 did not maintain that the Japanese were the formidable enemy they proved to be during the opening stages of the Pacific War. Nor did the Americans conclude that the IJA was an easy opponent. Evaluations of the Japanese showed an understanding of the complexities which lay behind their combat techniques, and paid due heed to two key features. First, the mounting defeats suffered by the enemy revealed a key shortcoming, namely its inability to compete with the Allies in terms of the provision and tactical deployment of mechanized forces. When faced with opponents who possessed greater resources and combat skill, the Japanese were unable to retain their garrisons in the Pacific. Secondly, in spite of its difficulties it faced, the IJA continued to demonstrate a capacity to impose delay and attrition on its opponents, thereby posing obstacles to the Allied counter-offensive.

The situation required the US Army to undertake a number of measures to improve its own tactical methods, so that it could fight the Japanese effectively While adequate resources were an important ingredient for victory, the proper application of Allied material superiority vis-à-vis the IJA was often crucial. Intelligence on Japanese combat methods played an essential part in paving the way for the US Army's victories in the Asia-Pacific theaters. It helped field commanders to determine enemy weaknesses that were open to exploitation, as well as strengths which US forces needed to cope with. At

${ }^{142}$ Cannon, Leyte, p.247 
the same time, gaining a proper knowledge of the IJA was the first step towards conducting a successful campaign. Military intelligence formed the basis for the development of tactical doctrine, by providing critical information on the elements which US forces faced. Combat experience enabled army commanders to learn how to overcome the challenges.

The main problem facing the US Army during the initial stages of the Pacific War was that the majority of its units were not familiar with Japanese tactical methods, nor did they know which measures they needed to take in order to defeat their opponent. Nevertheless, the Americans did have a number of valuable assets. Army doctrine called for fighting a combined arms battle, which called for the coordinated deployment of supporting weapons and infantry units. The practice was crucial for neutralizing Japanese forces in the battlefield conditions that prevailed in the Pacific theaters. The main task was to apply the US Army's existing concepts in a manner that was suitable for defeating the Japanese army. Army commanders such as Robert Eichelberger and Walter Krueger were willing to undertake a meticulous effort to learn the strengths and weaknesses of the IJA's combat methods. They also analyzed the lessons they learned from combat experiences, and thereafter determined which practices were most suitable, while at the same time identifying any mistakes that were made.

In offensive operations against Allied positions, the Japanese demonstrated their skill at employing their troops to infiltrate and outflank enemy defenses. US forces needed to maintain a constant vigilance of the battlefield in order to avoid being caught off guard, while at the same time establishing perimeter defenses that did not leave any gaps through which the Japanese could penetrate. Defending forces needed to neutralize enemy attacks with firepower, while at the same time relying on infantry units to hold their ground without being overwhelmed. The IJA's defensive tactics also posed significant challenges. The Japanese managed to construct bunkers that could withstand bombardment, while at the same time using natural features such as hilly terrain and caves to bolster the resilience of their positions. US forces needed to use their supporting arms effectively to neutralize enemy defenses sufficiently so that the infantry could 
advance without incurring excessive losses. Even then, infantrymen needed to undertake a number of crucial tasks, such as ascertaining the strength and location of enemy defenses, so that adequate amounts of supporting fire could be directed at the correct places. Last but not least, foot soldiers had to occupy Japanese positions and mop-up the remnants of resistance.

By the closing stages of the Pacific campaigns, US army personnel were confident that their troops had developed the capacity to defeat the IJA. Nevertheless, the Americans were still reluctant to dismiss the challenges they faced. In spite of their deficiency in modern weaponry, the Japanese proved capable of introducing nominal improvements which posed additional obstacles for the Allies. Enemy defense positions also showed increasing levels of resilience, thereby requiring US forces to improvise their tactics and equipment. Military intelligence kept the army establishment informed on the challenges it faced. While material resources and the development of an effective tactical doctrine were necessary for success, intelligence provided a vital instrument which enabled US troops to defeat the Japanese, by helping them identify possible ways to deploy their military strength, so that they could defeat the IJA in an efficient manner. 